\title{
Alles naar wens? Observaties naar aanleiding van het conceptwetsvoorstel ter aanvulling van het spreekrecht voor slachtoffers en nabestaanden in het strafproces
}

\author{
Renée Kool
}

\section{Inleiding}

Aanleiding tot deze bijdrage is het Nederlandse conceptwetsvoorstel ter aanvulling van het spreekrecht voor slachtoffers en nabestaanden in het strafproces. ${ }^{1}$ Het wetsvoorstel sluit aan op de evaluatie van het spreekrecht uit 2010 (Lens c.s., 2010), de daaropvolgende wetswijzigingen en maakt deel uit van de beleidsvoornemens die zijn afgesproken in het regeerakkoord van het kabinet-Rutte II (Bruggen slaan, oktober 2012). Inmiddels hebben diverse adviesorganen (kritisch) geadviseerd. De Raad voor de rechtspraak en het Fonds Slachtofferhulp zijn beide van mening dat er onvoldoende 'vraag' is naar een adviesrecht: met de invoering ervan zou enkel worden tegemoetgekomen aan de wens van een beperkte groep slachtoffers (Raad voor de rechtspraak, 2013: 5 en 6; Fonds Slachtofferhulp, 2013: 2). Slachtofferhulp Nederland daarentegen is positief en meent dat het adviesrecht een meerwaarde heeft voor slachtoffers (Slachtofferhulp Nederland, 2013). Het door de Raad voor de rechtspraak en het Fonds Slachtofferhulp geopperde bezwaar vindt echter steun in victimologisch onderzoek. Daaruit blijkt dat de slachtofferbehoeften uiteenlopend van aard zijn en zeker niet steeds gericht op ver(der)gaande zeggenschap. Los van dit victimologische bezwaar zijn ook uit juridisch oogpunt kanttekeningen te plaatsen bij het conceptwetsvoorstel. Aanleiding genoeg dus om er een (kritische) bespreking aan te wijden. Omdat de Vlaamse lezers wellicht onvoldoende bekend zijn met de Nederlandse ontwikkelingen, schets ik die kort (par. 2), waarna ik inga op (recent) victimologisch onderzoek naar slachtofferbehoeften, in het bijzonder inzake het verwerven van zeggenschap (par. 3). Met dit beeld in het achterhoofd volgt een beschrijving van de wijze waarop het spreekrecht en zijn schriftelijke pendant, de schriftelijke slachtofferverklaring (hierna: SSV) in de praktijk wordt toegepast (par. 4). Dit alles vormt de opmaat naar een uiteenzetting van de inhoud van het conceptwetsvoorstel (par. 5) en de daaropvolgende waardering in het licht van victimologische bevindingen en juridische merites (par. 6). Ik sluit af met een korte conclusie (par. 7). Vooropgesteld zij dat het voorstel om te komen tot invoering van een

1 Zie www. rijksoverheid.nl/documenten-en-publicaties/wetsvoorstellen/2014/04/16/wijzigingstrafvordering-ivm-verdere-verbetering-positie-slachtoffer-o-a-uitbreiding-spreekrecht. 
adviesrecht voor slachtoffers beleidsmatig niet wordt gelinkt aan herstelrecht. Niettemin zal ik, waar mogelijk, daaraan relateren.

\section{2. (Recente) ontwikkelingen}

Nederlandse slachtoffers kunnen sinds 2005 gebruikmaken van het spreekrecht. Destijds ingevoerd als gevolg van een initiatiefwetsontwerp, maakt het spreekrecht sinds 2011 deel uit van de wettelijke catalogus van slachtofferrechten (art. 51e titel IIIA Wetboek van Strafvordering (Sv)). Spreekgerechtigd zijn het slachtoffer of diens nabestaanden en, wanneer het slachtoffer niet bekwaam is te spreken, diens vertegenwoordiger. Voorwaarde is dat het ernstige misdrijven betreft (gevangenisstraf van acht jaar of meer en enkele in de wet genoemde misdrijven). Uitgangspunt is dat maximaal drie belanghebbenden het spreekrecht mogen uitoefenen ${ }^{2}$ en dat deze verklaring zich beperkt tot het spreken over de gevolgen die het (tenlastegelegde) strafbare feit heeft gehad voor het slachtoffer of diens nabestaanden. Op die manier wordt voorkomen dat het slachtoffer zich uitlaat over de feiten en zich zodoende zou bemoeien met de waarheidsvinding en/of de straftoemeting. Dat laatste zou namelijk in beginsel betekenen dat het slachtoffer als getuige (beëdigd) kan worden gehoord. Dat zou aanleiding kunnen geven tot secundaire victimisatie. Dat laat onverlet dat over de in het kader van het spreekrecht afgelegde verklaring vragen mogen worden gesteld door de verdediging, het Openbaar Ministerie en de rechter ambtshalve. Deze vragen worden middellijk via de behandelend rechter gesteld, die doorvoering ervan kan beletten. Hoewel een adequate registratie ontbreekt, wordt het aantal strafzaken waarin gebruik wordt gemaakt van het spreekrecht, geschat op circa 250 op jaarbasis. Naast het spreekrecht is er ook de mogelijkheid voorafgaand aan de zitting een schriftelijke slachtofferverklaring (hierna: SSV, ook wel Victim Impact Statement genoemd) op te (doen) stellen. Daarvan wordt naar schatting 3000 keer per jaar gebruikgemaakt (Leferink \& Vos, 2008; Lens c.s., 2010). De SSV wordt als schriftelijk bescheid gevoegd in het strafdossier (art. 51a jo. 344 lid 1 sub 5 Sv); ${ }^{3}$ van de uitoefening van het spreekrecht wordt verslag gedaan in het proces-verbaal van de zitting. Beide maken deel uit van het strafdossier dat ten grondslag ligt aan de rechterlijke besluitvorming. Overigens is de SSV een buitenwettelijke figuur, maar omdat zij deel uitmaakt van het via de Aanwijzing Slachtofferzorg (2010) voorgeschreven dienstenaanbod van het Openbaar Ministerie, kan het slachtoffer er wel een zekere (rechts)aanspraak op maken. ${ }^{4}$ De vraag of, en zo ja op welke wijze beide een rol kunnen spelen bij het bewijs respectievelijk de straftoemeting komt

2 Eerder was dit beperkt tot één spreekgerechtigde.

3 Hoewel een SSV vormvrij is en door het slachtoffer zelf kan worden opgesteld, wordt in de praktijk meestal gebruikgemaakt van de diensten van een daartoe aangestelde slachtoffermedewerker in dienst van Slachtofferhulp Nederland (SHN).

4 Beleidsregels van het Nederlands Openbaar Ministerie neergelegd in gepubliceerde Aanwijzingen gelden als 'recht' in de zin van art. 99 RO en zijn uit dien hoofde in te roepen. Overigens zijn ook de wettelijke slachtofferrechten (titel IIIA Sv) niet in rechte afdwingbaar, met uitzondering van de voeging van de benadeelde partij (art. 51f Sv). Handhaving verloopt bij de rechter langs de band van de algemene beginselen van een behoorlijke procesorde. 
in paragraaf 4 aan de orde. Hier volsta ik ermee op te merken dat de rechtspraktijk, met uitzondering van de advocatuur, na aanvankelijke aarzeling (gematigd) positief is over de SSV en het spreekrecht.

Met de invoering van het spreekrecht was het einde van de uitdijende slachtofferparticipatie echter niet in zicht, integendeel. Het huidige kabinet (Rutte II) maakte bij zijn aantreden in het najaar van 2012 duidelijk dat het streven naar een (verdere) verbetering van de slachtofferpositie speerpunt van beleid is. Het actieve slachtofferbeleid ingezet onder het kabinet-Rutte I werd opgevoerd en gedocumenteerd in het visiedocument 'Recht doen aan slachtoffers' (Ministerie van Veiligheid \& Justitie, 2013). Een van de voornemens betreft de invoering van een adviesrecht voor slachtoffers. Daarover was eerder gedebatteerd in het kader van de evaluatie van het spreekrecht, maar vrees voor secundaire victimisatie (vanwege mogelijke toepassing van het ondervragingsrecht) en de daarmee samenhangende vraag of zou moeten worden overgegaan tot een splitsing van het strafproces weerhielden de wetgever destijds van invoering. ${ }^{5}$ Nadat de laatste vraag op grond van (rechtsvergelijkend) onderzoek negatief was beantwoord (Keulen c.s., 2014), is alsnog besloten tot het indienen van een (concept)wetsvoorstel strekkende tot invoering van een adviesrecht. Dat het de regering-Rutte II ernst is met het creëren van een wettelijke basis waarop slachtoffers medezeggenschap kunnen hebben, blijkt uit de volgende passage, afkomstig uit het visiedocument 'Recht doen aan slachtoffers': 6

'Om recht te doen aan slachtoffers is het belangrijk dat daders worden gestraft en dat de straf als passend wordt ervaren. Niet alleen de feitelijke uitkomst en de strafmaat bepalen de tevredenheid met de uitkomst van het strafproces, maar ook de mate waarin het proces zelf als rechtvaardig wordt ervaren (procedurele rechtvaardigheid). Daarvoor is het belangrijk dat slachtoffers zijn geïnformeerd en dat zij invloed kunnen uitoefenen op de uitkomst. Dit betekent echter niet dat het slachtoffer van een deelnemer met rechten moet worden tot een volwaardige procespartij met eigen vervolgingsrecht' (Ministerie van Veiligheid \& Justitie, 2013: 16). ${ }^{7}$

\section{Heterogene slachtofferbehoeften}

Als opgemerkt hebben verschillende adviesorganen erop gewezen dat slechts een selecte groep slachtoffers behoefte lijkt te hebben aan een adviesrecht (Raad voor de rechtspraak, 2013: 5 en 6; Fonds Slachtofferhulp, 2013: 2). Dat bezwaar stemt overeen met victimologische bevindingen: vastgesteld is dat slachtofferbehoeften sterk uiteenlopen (Ten Boom \& Kuijpers, 2007; Laxminaryan, 2012; Lens c.s.,

$5 \quad$ Kamerstukken II 2011-2012, 33 176, nr. 8; Kamerstukken II 2011-2012, 33 176, nr. 6, p. 10-11; Kamerstukken II 2011-2012, 33 176, nr. 9, p. 31, met verwijzing naar HR 6 maart 2012, ECLI:NL:HR: BR1149 (ook: NJ 2012, 367 m.nt. C.P.M. Cleiren).

6 Opgemerkt moet worden dat de beleidsvoornemens ook zien op een verbreding van de toepassing van herstelrecht; Ministerie van V\&J, 2013, par. 3.2.3.

$7 \quad$ Zie ook Ministerie V\&J, 2014: 9, waar wordt gerefereerd aan de doelstelling te komen tot het 'realiseren van een sterke, wettelijk verankerde positie in het recht'. 
2014). Overigens wordt dit inmiddels onderkend door de wetgever: waar in de beginjaren in beleidsstukken nog werd uitgegaan van een te eendimensionaal slachtofferprofiel, geeft de wetgever zich tegenwoordig rekenschap van het feit dat slachtoffers een samengestelde groep vormen met uiteenlopende verwachtingen (Ministerie van Veiligheid \& Justitie, 2013: 11-12). Daaronder bevindt zich, zo is gebleken uit de evaluatie van het spreekrecht, ook een groep die behoefte heeft aan een verruiming van zeggenschap over 'hard core' juridische kwesties, in het bijzonder de straftoemeting (Lens c.s., 2010). Het betreft echter een specifieke groep, namelijk degenen op wie het delict de zwaarste impact heeft gehad. Dat laatste impliceert niet per se dat het om de zwaarste delicten gaat, maar in de regel is daarvan wel sprake. Het is de behoefte van deze groep slachtoffers, waaraan de wetgever heeft gemeend tegemoet te moeten komen met het conceptwetsvoorstel.

$\mathrm{Nu}$ is de politieke beleidsfocus op procedural justice, in het bijzonder op victim voice niet nieuw, integendeel. Victimologen dringen er echter steeds vaker op aan om oog te houden voor de variëteit van slachtofferbehoeften. Onderzoek leert dat de aard en omvang van slachtofferbehoeften afhankelijk zijn van (interne en externe) variabelen. In het bijzonder de impact die het delict heeft gehad op het slachtoffer is van belang, maar ook externe variabelen (bijvoorbeeld de kwaliteit van de bejegening of de kwaliteit van de leefomgeving) zijn van invloed. De laatste constitueren immers tot op zekere hoogte de post-slachtofferervaring en staan in wisselwerking met interne slachtofferkenmerken (Wemmers \& Cyr, 2004; Pemberton \& Reynaers, 2011; Lens c.s., 2010; Laxminaryan, 2012; Lens c.s., 2013; Timmermans c.s., 2013). Daarbij komt dat onderscheid moet worden gemaakt in de doelen van victim voice. Slachtofferbehoeften omvatten namelijk zowel de wens tot uitkomstcontrole als de wens tot procescontrole. Welke van de twee prioriteit heeft, is onduidelijk. ${ }^{8}$ Beide doelen interfereren, zodat het moeilijk is om vast te stellen welk doel de voorkeur heeft, maar de schaal lijkt door te slaan naar procescontrole (Roberts \& Erez, 2004; Wemmers \& Cyr, 2004). Duidelijk is wel dat participatoir ingestelde slachtoffers het op prijs stellen van meet af aan te worden betrokken bij de afhandeling van het delict. Dat laatste moet echter niet worden begrepen als synoniem voor een streven naar uitkomstcontrole, integendeel. Positieve percepties over geboden victim voice kunnen dempend werken op de behoefte aan uitkomstcontrole en negatieve evaluaties ter zake relativeren (Lens c.s., 2010; Timmermans c.s., 2013: 25). Over de hele linie genomen blijken slachtofferbehoeften wat betreft het participatoire aspect het midden te houden tussen verzet tegen volledige uitsluiting en het afhouden van volledige betrokkenheid (Erez \& Tontodonato, 1992; Wemmers, 2009: 412; Cassell \& Erez, 2011; Englebrechts, 2011).

Niettemin wijzen de Nederlandse evaluaties van het spreekrecht en de SSV uit dat een substantieel cohort slachtoffers (onder andere) participeert in de hoop de strafmaat te beïnvloeden (Kool c.s., 2006; Leferink \& Vos, 2008). Volgens Lens c.s. betreft het zelfs de helft van de spreekgerechtigden en een kwart van degenen die een SSV hebben opgesteld (Lens, 2010: 85). Gemeenschappelijk kenmerk van 
deze groep slachtoffers is de hoge impact die het delict op hen (of hun nabestaanden) heeft gehad, waardoor de bereidheid tot het gebruikmaken van het spreekrecht hoog is (Leferink \& Vos, 2008; Lens c.s., 2010). Tegelijkertijd laten (dezelfde) studies (ook) zien dat een substantieel deel van de slachtoffers een voorkeur heeft om niet actief deel te nemen aan het strafproces (Leferink \& Vos, 2008; Lens c.s., 2010; Lens c.s., 2013; Laxminaryan, 2012). De motieven om af te zien van het spreekrecht lopen uiteen: sommige slachtoffers zien op tegen de formaliteit van de strafzitting en/of de (emotionele) confrontatie met de verdachte, anderen willen gewoonweg niet worden herinnerd aan het strafbare feit of ervaren slechts een geringe impact.

Bij dit alles moet voor ogen worden gehouden dat het spreekrecht, of enige andere vorm van slachtofferparticipatie, de zittingsefficiëntie niet in de weg mag staan. Als regel geldt dat de uitoefening van het spreekrecht niet meer dan tien tot vijftien minuten in beslag mag nemen. Dergelijke organisatorische, buiten de macht van het slachtoffer liggende overwegingen zijn medebepalend voor diens 'bejegeningservaring' en kunnen oorzaak zijn van secundaire victimisatie. Ter nuancering moet echter worden opgemerkt dat observaties van de zittingspraktijk erop duiden dat de rechter in de praktijk niet altijd strikt de hand houdt aan de tijdslimiet, noch aan de overige grenzen van het spreekrecht (Lens c.s., 2010; ook Leferink \& Vos, 2008). Van belang, tot slot, is te vermelden dat victimologen benadrukken dat het spreekrecht geen synoniem is voor therapeutische effecten. Het spreekrecht kán weliswaar bijdragen aan de verwerking van het overkomen delict, maar het primaire effect ligt vooral in de door het slachtoffer ervaren erkenning ( procedural justice). Kortom: victimologisch onderzoek biedt onvoldoende steun om aan te nemen dat er een eenduidige, substantiële slachtofferbehoefte bestaat aan een adviesrecht.

\section{Uitkomstcontrole en grensbewaking}

Als gezegd, hangt de betekenis van het spreekrecht voor het individuele slachtoffer af van interne en externe variabelen. Eén van die externe variabelen is de wijze waarop de rechter het spreekrecht ter zitting operationaliseert. Voor een goed begrip van de toepassing van victim voice ter zitting is het van belang oog te hebben voor de onderliggende procestraditie. De praktische betekenis van het spreekrecht - en mutatis mutandis van overige vormen van slachtofferparticipatie - wordt immers (mede) bepaald door de processuele context waarin het slachtoffer zijn stem kan doen gelden. Nu het adviesrecht volgens de wetgever moet worden begrepen als uiting van adversariteit, is een korte uitweiding op zijn 
plaats (Conceptwetsvoorstel, 2013:21). ${ }^{9}$ Vooropgesteld moet worden dat het opmerkelijk is dat er, althans naar mijn weten, weinig victimologisch onderzoek is gedaan naar dit aandachtspunt. Het maakt namelijk wezenlijk verschil of je je als slachtoffer processueel manifesteert in een inquisitoire of een adversaire procestraditie. Het eerste ziet op de procestraditie waarin het slachtoffer geen partij is, maar waarin diens belangen onderdeel uitmaken van het algemeen belang, behartigd door de Staat, via het Openbaar Ministerie. De tweede vorm heeft betrekking op de Angelsaksische procestraditie en gaat ervan uit dat strafvervolging (in beginsel) een private aangelegenheid is, een rechtsstrijd derhalve tussen twee gelijkwaardige partijen (slachtoffer vs. verdachte). ${ }^{10}$ Duidelijk moge zijn dat beide tradities, hoewel er een zekere toenadering is, verschillende vertrekpunten hebben over wie verantwoordelijk is voor strafvervolging en voor het daaropvolgende proces van waarheidsvinding en bestraffing. Aangenomen wordt dat de eerste, waartoe Nederland behoort, zich beter leent voor de receptie van slachtofferparticipatie dan haar tegenhanger, het adversaire model (Bednarova, 2011; McGoonigle, 2012). Dit verklaart waarom de Nederlandse wetgever vergaande voorstellen kan doen als de onderhavige invoering van een adviesrecht. Weliswaar stuit dit ook binnen onze strafrechttraditie op wetssystematische problemen, maar die zijn altijd nog van mindere omvang dan elders het geval is (Kool \& Verhage, 2014). Hoewel ik deze 'variabele' hier niet verder bespreek, moet zij wel in het achterhoofd worden gehouden: de onderliggende rechtstraditie vormt immers het forum waarbinnen de rechtspolitieke keuzen betreffende victim voice en daarmee samenhangend de waardering daarvan door slachtoffers, moeten worden geduid (zie verder par. 5).

Hoe wordt in de Nederlandse context door de strafrechter omgegaan met het spreekrecht, in het bijzonder in het licht van de uitkomsten van het strafproces? Gelet op het feit dat het adviesrecht tot doel heeft het slachtoffer een stem te geven die kan bijdragen aan de 'volle' rechterlijke besluitvorming, is het zinvol om na te gaan in hoeverre het huidige spreekrecht en de SSV daarop al van invloed zijn en in hoeverre dit spanning oproept. Immers, wanneer blijkt dat het mindere - het spreekrecht en de SSV - aanleiding geven tot te vergaande beïnvloeding van de rechterlijke besluitvorming of een bedreiging vormen voor het gewaarborgde karakter van het strafproces, zal dat zeker gelden voor het meeromvattende

9 De letterlijke verwijzing naar 'adversariteit' in het conceptwetsvoorstel heeft betrekking op de veronderstelling van de wetgever dat het adviesrecht de mogelijkheid tot tegenspraak tussen slachtoffer en verdachte versterkt. In het klassieke, inquisitoire Nederlandse strafproces bestaat die tegenspraak enkel tussen het Openbaar Ministerie en de verdachte. De wetgever haakt met de introductie van deze term aan bij het 'on-Nederlandse' adversaire proces, als toegepast in de Angelsaksische landen. Zo'n onvoldoende doordacht gebruik van wat in vaktermen een legal transplant wordt genoemd, is echter problematisch. Hier roept het de suggestie op dat het beoogde adviesrecht resulteert in werkelijke tegenspraak, waarvan geen sprake is.

10 Voor de goede orde wijs ik erop dat de klassieke tegenstelling inquisitoir/adversair (ook wel aangeduid met de tegenstelling civil law/common law) duidt op archetypes en enigszins achterhaald is. Naast de voor de beide tradities onderscheidende kenmerken is ook binnen de tradities zelf sprake van aanpassingen; zo wordt het Nederlandse strafproces tegenwoordig aangeduid als gematigd inquisitoir. 
adviesrecht. Vooropgesteld moet worden dat noch het spreekrecht, noch de SSV destijds is ingevoerd met het doel de rechterlijke besluitvorming te sturen. Wel is van meet af aan gesteld dat beide ertoe strekken de rechter en de officier van justitie te informeren, zodat deze kunnen komen tot een meer volledige, meer adequate besluitvorming. Van een 'harde' aanspraak van het slachtoffer op een stem in de straftoemeting was en is echter geen sprake.

De praktijk heeft zich aan deze opdracht van de wetgever gehouden en laat zien dat beide rechtsfiguren worden gebruikt om de strafeis/strafoplegging te finetunen; rechters en officieren van justitie menen de gevolgen van het delict voor het slachtoffer ambtshalve al goed te kunnen inschatten (Kool, 2006; Leferink \& Vos, 2008; Lens c.s., 2010). Bedacht moet ook worden dat de ruimte voor inbreng door het slachtoffer binnen het Nederlandse format beperkt is vanwege gebondenheid aan straftoemetingsrichtlijnen en -afspraken (Kool, 2014). Tegelijkertijd lijkt de rechter bereid te zijn om dit 'gebrek' aan formele zeggenschap tot op zeker hoogte te compenseren door het slachtoffer toe te staan bij de uitoefening van het spreekrecht respectievelijk het opstellen van een SSV over de grenzen van de wet te gaan. Hoewel zeker niet vast is komen te staan dat het overschrijden van de wettelijke grenzen schering en inslag is in de zittingszaal en/of blijkt uit rechterlijke uitspraken, zijn er genoeg voorbeelden te vinden die wijzen op het bieden van een zeker tegenwicht tegen de door de wet gestelde grenzen waar het slachtoffer bij het spreken respectievelijk schrijven tegenaan loopt. Rechters geven echter wel aan dat deze flexibele houding moet worden bezien tegen de achtergrond van de wens gelegenheid te geven tot victim voice gericht op procescontrole; er is geen sprake van een bereidheid de behoefte aan uitkomstcontrole te faciliteren (Kool c.s., 2006; Leferink, 2008; Lens c.s., 2010). Dit stemt overeen met bevindingen elders, waaruit eveneens blijkt dat de impact van victim voice via Victim Impact Statements beperkt is en feitelijk wordt geneutraliseerd (Erez \& Tondonoato, 1997; Roberts \& Erez, 2004; Kool \& Verhage, 2014).

Niettemin kan de uitoefening van victim voice via het spreekrecht en/of een SSV wel de indruk wekken van beïnvloeding. Daartegen is vanuit verdedigingsperspectief bezwaar gemaakt, wat heeft geleid tot jurisprudentie. Wanneer we de stand van zaken daaruit opmaken, blijkt dat de Hoge Raad het participerende slachtoffer niet ongenegen is. Hoewel hij om formele redenen meent strikt de hand te moeten houden aan de beperkingen die de wetgever heeft gesteld aan de categorie spreekgerechtigden, ${ }^{11}$ voert hij met betrekking tot de buitenwettelijke rechtsfiguur van de SSV een ruimere koers. Die mag zowel voor het bewijs als voor de straftoemeting worden gebruikt, zij het dat 'de rechter het gewicht van de inhoud van de verklaring van het slachtoffer of diens nabestaande als bedoeld in art. 302 (oud) Sv en van de inhoud van de verklaring zal behoren te beperken tot een accentuering (curs. RK) van het beeld dat reeds uit het (overigens) verhandelde ter

11 HR 6 maart 2012, NJ 2012, 367 m.nt. C.P.M. Cleiren, ECLI:NL:HR:2012:BR1149. Overigens is na wijzing van dit arrest de categorie spreekgerechtigden uitgebreid, Stb. 2012, 345 resp. 370. 
terechtzitting is verkregen'. ${ }^{12}$ Daarmee wordt, zoals Borgers heeft betoogd, een zekere, zij het bescheiden, opening tot uitkomstcontrole gecreëerd. ${ }^{13}$ Dat wordt opgeroepen tot een relatief bescheiden gebruik van de SSV door de zittingsrechter, vindt zijn grondslag overigens in de (juridische) noodzaak het processuele evenwicht tussen Openbaar Ministerie en verdediging te behouden: in een gematigd inquisitore procestraditie noodzaakt de gewaarborgde waarheidsvinding ertoe de verdachte (op enigerlei wijze) de gelegenheid te bieden tegen hem ingebrachte bronnen te kunnen bevragen. Het slachtoffer wordt behandeld als getuige en staat bloot aan het risico op aanhouding wegens meineed (zij het dat een dergelijke aanhouding uitzonderlijk is). Zo'n directe ondervraging naar aanleiding van de uitoefening van het spreekrecht of hetgeen is ingebracht via een SSV kan leiden tot secundaire victimisatie. Door een zeker voorbehoud te maken met betrekking tot de betekenis van de SSV, beperkt de Hoge Raad de noodzaak tot ondervraging en spaart hij de kool (de rechtsbescherming van de verdachte) en de geit (de rechtsbescherming van het slachtoffer).

\section{Het voorgestelde adviesrecht}

Duidelijk is dat de voorgestelde verruiming van artikel 51e Sv een majeure aanpassing betreft van de Nederlandse strafvordering. Waar het spreekrecht tot nog toe beperkt diende te blijven tot het spreken/informeren over de gevolgen van het (ten laste gelegde) misdrijf, strekt het adviesrecht ertoe 'mogelijk te maken dat degenen die bevoegd zijn gebruik te maken van het spreekrecht op de terechtzitting ook hun opvatting over de omvang van de bewezenverklaring, de kwalificatie van het feit, de schuld van de verdachte en de passende straftoemeting kenbaar te maken' (Conceptwetsvoorstel, 2013: 5). Het hoeft geen betoog dat dit alle, de rechterlijke besluitvorming constituerende rechtsvragen omvat. ${ }^{14}$ In rechtsvergelijkend opzicht is het adviesrecht dan ook het best te vergelijken met de uit het Amerikaanse recht bekende Victim Statement of Opinion, met dien verstande dat daar sprake is van gescheiden procedures (Kool \& Verhage, 2014). De uitoefening van het adviesrecht staat overigens los van de (voorafgaande) uitoefening van het spreekrecht en/of de inbreng van een SSV. Het vormt een derde, extra voorziening. Niettemin staat het het slachtoffer vrij om het spreekrecht en het adviesrecht aaneensluitend uit te oefenen (Conceptwetsvoorstel, 2013: 19). Net als het spreekrecht en de SSV is de uitoefening van het adviesrecht gepositioneerd vóór het requisitoir van de officier van justitie; deze kan daaraan zodoende in zijn eis refereren.

12 HR 11 oktober 2011, NJ 2011, 558 m.nt. J. Reijntjes, ECLI:NL:HR:2011:BR2359 (r.o. 3.6.1). Voorts: HR 6 november 2012, NJ 2013, 86 m.nt. M.J. Borgers, ECLI:NL:HR:2012:BR2359; conclusie A-G Vegter bij HR 20 maart 2012, ECLI:NL:HR:2012:BV2855 en Hof Den Bosch 6 januari 2014, ECLI:NL:HR:GHSHE:2012:1.

13 In diens annotatie onder HR 6 november 2012, NJ 2013, 86.

14 Binnen het Nederlands bestel liggen die vragen besloten in art. $350 \mathrm{~Sv}$, dat samen met art. 348 en 349 het zogenoemde beslissingsmodel vormt. 
Als gezegd omvat de medezeggenschap die het slachtoffer in het kader van het adviesrecht wordt toebedeeld meerdere aspecten. Dit roept gelet op het specifieke karakter van de te beantwoorden juridische aandachtpunten de vraag op of en in hoeverre het slachtoffer in staat zal zijn daaraan eigenhandig een adequate bijdrage te leveren. Slachtofferhulp Nederland stelt weliswaar dat het uitgangspunt wat betreft de beslissing van het slachtoffer om te participeren moet liggen in 'zelfredzaamheid' (Slachtofferhulp Nederland, 2013: 2), maar het strafproces vormt een sterk formeel, gecompliceerd gebeuren dat voor leken veelal niet goed is te doorgronden. De Raad voor de rechtspraak vreest dan ook voor een juridisering van de rol van slachtoffers en voorziet dat de uitoefening van het adviesrecht gepaard zal gaan met een uitbreiding van de rechtsbijstand, waardoor de beoogde 'eigen bijdrage' van het slachtoffer verloren dreigt te gaan (Raad voor de rechtspraak, 2013: 8). ${ }^{15}$ Dat accentueert de noodzaak tot adequate voorbereiding van het slachtoffer en een juiste zittingsregie, ${ }^{16}$ maar ook dan blijven er risico's aanwezig voor secundaire victimisatie. ${ }^{17} \mathrm{Zo}$ biedt het adviesrecht het slachtoffer de mogelijkheid om een verzoek te doen om aanvullende onderzoekshandelingen te (laten) verrichten. De rechter is echter niet verplicht daarop in te gaan en zal dit, gelet op het feit dat de zaak (naar mag worden aangenomen) zorgvuldig is voorbereid door het Openbaar Ministerie, ook niet snel doen, maar de gelegenheid is daar. Beslissend is of de gevraagde onderzoekshandeling naar het oordeel van de rechter van betekenis is voor de waarheidsvinding en of zij strikt noodzakelijk is. Zo'n afwijzing op grond van het - overigens terecht - strikte criterium kan secundaire victimisatie oproepen (Raad voor de rechtspraak, 2013: 7). Mutatis mutandis geldt hetzelfde voor een advies van het slachtoffer over de kwalificatie- of de schuldvraag. Voor de straftoemeting ligt dit wellicht iets anders. Daarvoor geldt dat de rechter, indien hij substantieel afwijkt van het strafadvies van het slachtoffer, verplicht is opgave van redenen te doen in het vonnis. ${ }^{18}$

Opvallend in dit verband en in tegenstelling tot de huidige ontwikkeling naar het optuigen van een professionele slachtofferadvocatuur, is dat de wetgever het niet nodig vindt het slachtoffer ten behoeve van de uitoefening van het adviesrecht

15 Vgl. Ministerie van Veiligheid \& Justitie 2013:15, waar wordt gesteld dat het slachtofferbeleid beoogt tegemoet te komen aan de wens van het geëmancipeerde slachtoffer om, naast de wens adequaat te worden geïnformeerd, 'ook zelf actief een bijdrage' te leveren aan het strafproces.

16 De Raad vreest voor een juridisering van de rol van slachtoffers en voorziet dat de uitoefening van het adviesrecht gepaard zal gaan met een uitbreiding van de rechtsbijstand, waardoor de beoogde 'persoonlijke victim voice' verloren gaat.

17 Vgl. art. 288a Sv, waarin de rechter wordt geïnstrueerd het slachtoffer correct te bejegenen. Art. 51a lid 2 Sv bevat zo'n instructie voor het Openbaar Ministerie. Zie ook Conceptwetsvoorstel 2013, 20, waar wordt gesproken van flexibele ordevoorschriften.

18 De Raad voor de rechtspraak werpt ook de vraag op wat een strafadvies toevoegt aan hetgeen bekend is uit hoofde van de SSV of het spreekrecht. Dat bezwaar is mijns inziens niet terecht, gelet op de aan deze voorzieningen gestelde beperkingen. Wanneer de Raad met dit argument mocht doelen op het gegeven dat rechters en officieren van justitie, binnen de bandbreedte die het straftoemetingsregime toelaat, goed in staat zijn de slachtofferbehoeften te verdisconteren in de strafeis respectievelijk de strafmaat heeft de Raad wel een punt (Raad voor de rechtspraak, 2013:7). 
rechtsbijstand toe te kennen (Fonds Slachtofferhulp, 2013: 3) ${ }^{19}$ Die mogelijkheid is er, maar wordt overgelaten aan - en komt dus voor rekening van - het slachtoffer. De uitoefening van het adviesrecht wordt, net als het spreekrecht, gezien als een persoonlijke aangelegenheid. Uitoefening via een raadsman zou, zo wordt aangenomen, door het slachtoffer als 'een kunstmatige breuk' worden ervaren (Conceptwetsvoorstel, 2013: 19). Hoewel dat kan worden uitgelegd als een teken dat het adviesrecht primair tot doel heeft te fungeren als mogelijkheid tot expressie (victim voice), liggen er ongetwijfeld ook financiële overwegingen aan ten grondslag.

\section{Waardering}

Hoe het voorstel tot invoering van een adviesrecht te waarderen? Het antwoord op die vraag ligt gecompliceerd, want juridische argumenten moeten worden verzoend met victimologische overwegingen. Weliswaar stelt het visiedocument 'Recht doen aan slachtoffers' dat 'het onjuist is de verhoudingen alleen te bezien in termen van communicerende vaten' (Ministerie van Veiligheid \& Justitie, 2013:6), de prangende vraag is toch hoe het voor een gewaarborgd proces benodigde evenwicht te behouden. Dat het adviesrecht spanning oproept met de - nog steeds geldende uitgangspunten - van het Nederlandse strafproces is evident. Ook de wetgever houdt daaraan in beginsel vast, immers: 'aan het slachtoffer komt, omdat hij geen procespartij is, geen eigen oordeel toe over de totale omvang van het onderzoek' (Conceptwetsvoorstel, 2013: 22; zie ook p. 17). En verderop: 'Het strafproces is erop ingericht om het slachtoffer een beperkte stem (curs. RK) in de rechtszaal te geven' (Conceptwetsvoorstel, 2013: 20). Niettemin begint het er om 'te spannen', want in een iets eerdere passage wordt opgemerkt dat het strafproces via het adviesrecht 'weliswaar een meer adversair karakter [krijgt; RK], maar dat speelt zich niet meer primair af tussen OM en verdediging, maar tussen de verdediging en het slachtoffer dat er veelal op uit zal zijn de verklaringen van de verdachte te ontkrachten' (Conceptwetsvoorstel, 2013: 21). Ook elders, in het genoemde visiedocument en de daarmee samenhangende Beleidsrapportage inzake de slachtofferzorg, klinkt de boodschap om te komen tot een omvattender herpositionering van de slachtofferpositie door (Ministerie van Veiligheid \& Justitie, 2013; 2014: 19). ${ }^{20}$

$\mathrm{Nu}$ is het anno 2014 onmiskenbaar dat het bieden van een adequate reactie aan het slachtoffer een zekere mate van participatie, in het bijzonder van victim voice,

19 In Nederland is op dit moment sprake van (verdergaande) professionalisering van de rechtsbijstand aan slachtoffers van ernstige geweld- en zedenzaken. Om in aanmerking te komen voor een toevoeging (lees: honorering van overheidswege) dienen advocaten een basisopleiding te hebben gevolgd en liefst een daarop volgende specialisatieopleiding. De eerste starten per september 2014; de tweede met ingang van januari 2015. E.e.a. hangt samen met de groei van (letsel)schadezaken en daaruit voortvloeiende schadevergoedingskwesties. Overigens geldt voor slachtoffers van ernstige geweld- en zedenmisdrijven al wel dat zij aanspraak hebben op kosteloze rechtsbijstand (art. 44 lid 4 Wet op de Rechtsbijstand), wat dus niet de kostenpost uitoefening adviesrecht omvat.

Over deze ambivalente opstelling ook: Raad voor de rechtspraak, 2013:4. 
impliceert. ${ }^{21}$ Waar dat laatste tendeert naar zeggenschap, doen zich echter de inherente beperkingen van het, op gematigd inquisitoire voet geschoeide, strafproces(recht) gelden. ${ }^{22}$ Immers, ook de verdachte heeft aanspraak op een voor hem adequate reactie, ofwel: op een gewaarborgd strafproces. Als gezegd wordt die boodschap nog steeds, en gelukkig maar, uitgedragen door de wetgever (Conceptwetsvoorstel, 2013: 17). Niettemin is de vraag hoe de uitoefening van het adviesrecht in een niet-gesplitste strafprocedure zich verhoudt tot de onschuldpresumptie. ${ }^{23}$ Sterker nog: de wetgever erkent, ja streeft zelfs na, dat de verdachte actief reageert op hetgeen door het slachtoffer naar voren wordt gebracht inzake de toedracht van de feiten (Conceptwetsvoorstel, 2013: 20).

Hier lijkt een aansluiting te liggen met het herstelrechtelijke gedachtegoed; ook daar ligt de focus immers op het bewerkstelligen van adequate communicatie, met als uitgangspunt dat de 'dader' verantwoordelijkheid neemt voor zijn handelen. Vooralsnog lijkt het conceptwetsvoorstel echter een andere toon te willen zetten en is van de voor het herstelrecht kenmerkende communicatieve wederkerigheid geen sprake. Dat komt niet alleen door de sterk formele setting waarin het adviesrecht zal worden toegepast, maar gewoonweg ook door de daaraan ten grondslag liggende doelen: die zijn vrijwel exclusief gericht op het bevorderen van het welzijn van het slachtoffer en de verhoging van de legitimiteit van rechterlijke besluitvorming.

De vraag is in hoeverre deze hybride positionering van de slachtofferpositie (geen erkenning als procespartij, maar wel een zekere zeggenschap over de uitkomsten) zich verhoudt tot de behoeften van de 'clientèle' (vgl. Raad voor de rechtspraak, 2013: 6). Het toekennen van zeggenschap impliceert immers ook dat het slachtoffer tot op zekere hoogte verantwoording krijgt te dragen voor de uitkomsten van het strafproces. De vraag of verruiming van inspraak ook gewenst is wanneer dit gepaard zou gaan met de toepassing van het ondervragingsrecht, is in de studies waarop de wetgever zich beroept echter niet gesteld. Sterker nog: de slachtoffers die aangeven behoefte te hebben aan ruimere zeggenschap, tonen zich ambivalent; zij geven namelijk tegelijkertijd aan dat een verruiming van inspraakmogelijkheden niet significant zou hebben bijgedragen aan hun tevre-

21 De adequate reactie vormt tegenwoordig de standaard voor het toetsen van het slachtofferbeleid en de wettelijke slachtofferpositie. De term is geïntroduceerd door Knigge en Groenhuijsen in het kader van het project Strafvordering 2001. Zie voor de daarin uitgezette contouren van de slachtofferpositie: Groenhuijsen \& Kwakman, 2001.

22 Het uitgangspunt dat het slachtoffer geen procespartij is en dat het vervolgingsmonopolie exclusief blijft toebedeeld aan het Openbaar Ministerie blijft namelijk onverlet (Conceptwetsvoorstel 2013:17). Het gesuggereerde adversaire karakter van het adviesrecht dient dan ook gerelativeerd te worden (Conceptwetsvoorstel, 2013: 21).

23 De wetgever meent dat een splitsing van het strafproces te ingrijpend zou zijn, omdat het slachtoffer in verschillende hoedanigheden, verspreid over de fasen van het strafproces, rechtsaanspraken kan doen gelden. Er zou, anders gezegd, geen concentratie van slachtofferparticipatie bewerkstelligd worden met een splitsing (Conceptwetsvoorstel, 2013: 9). Dat argument miskent evenwel dat een splitsing primair samenhangt met de wens de waarheidsvinding te onttrekken aan de invloedssfeer van het slachtoffer. 
denheid (Lens c.s., 2010: 80-81, 86-89). ${ }^{24}$ Overigens blijkt deze aan slachtofferbehoeften inherente ambivalente opstelling ook uit ander victimologisch onderzoek (Ten Boom \& Kuijpers, 2007). De studies die de wetgever aanvoert ter onderbouwing bevatten dan ook evenzovele - zo niet meer - victimologische handvatten die wijzen op onvoldoende draagvlak voor een zo verstrekkende figuur als het adviesrecht. De Raad voor de rechtspraak wijst daar in zijn advies terecht op en zet uit dien hoofde terecht vraagtekens bij de effectiviteit van het in te voeren adviesrecht (Raad voor de rechtspraak, 2013: 6). Wat de door de wetgever aangehaalde studies wel uitwijzen, is dat een substantieel cohort slachtoffers verruiming van victim voice wenst, maar niet hoe en onder welke voorwaarden (vgl. Wemmers, 2009). Ook kan worden opgemerkt dat op het niveau van de belangenorganisaties een zeker voorbehoud wordt gemaakt wanneer het gaat om het optuigen van de 'strafvorderlijke' verantwoordelijkheden van slachtoffers. Toegegeven, het ligt net wat anders, maar Victim Support Europe wijst een positie voor het slachtoffer als 'aanklager' principieel af vanwege de daaraan verbonden risico's op secundaire victimisatie (Victim Support Europe, 2013). En ook het Fonds Slachtofferhulp 2013 vreest daarvoor. ${ }^{25}$ Feitelijk is alleen Slachtofferhulp Nederland, en dat is weliswaar niet de minste organisatie in het veld, van mening dat dit risico gerelativeerd moet worden en kan worden voorkomen via een goede zittingsregie (Slachtofferhulp Nederland, 2013; Sas \& Crielaars, 2013; Sas, 2013). ${ }^{26}$ Dit laatste is wellicht waar, maar vormt eerder een argument om in te stemmen met het alternatief dat is voorgesteld door de Raad voor de rechtspraak, dan om in te stemmen met de invoering van een verstrekkende rechtsfiguur als het adviesrecht. Want ook de opponenten zien dat een verruiming van het huidige regime van het spreekrecht wenselijk is, maar bepleiten een minder radicale aanpassing dan voorgesteld door de wetgever. De Raad voor de rechtspraak op wiens leden de uitvoering van het spreekrecht rust, adviseert namelijk de wettelijke teugels te laten vieren, zodat de (zittings)rechter de ruimte krijgt om al naar gelang de omstandigheden van het geval het spreekrecht te doen uitoefenen op een zodanige wijze, dat tegemoet wordt gekomen aan de behoefte aan victim voice, maar tegelijkertijd wordt voldaan aan de eisen van een behoorlijk strafpro-

24 Deze - inherente - ambivalentie blijkt ook uit ander victimologisch onderzoek, bijvoorbeeld: Van Dongen c.s., 2012.

25 Zie ook: Raad voor de rechtspraak, 2013.

26 Opgemerkt kan worden dat het advies van Slachtofferhulp Nederland de intenties van de wetgever voorbij lijkt te streven. Het adviesrecht wordt vergeleken met de Duitse rechtsfiguur van de Nebenklager (Slachtofferhulp Nederland 2013:2; zie over deze rechtsfiguur de bijdrage van Kilchling in Tijdschrift voor Herstelrecht 2013, nr. 1). Invoering van zo'n rechtsfiguur staat gelet op de standpuntbepaling betreffende het vervolgingsmonopolie echter - wellicht nog - niet op het netvlies van de wetgever (Conceptwetsvoorstel 2013:17). Maar ook overigens lijkt het advies van Slachtofferhulp Nederland wat 'te positief'. Zo wordt de vraag gesteld waarom het slachtoffer als procesdeelnemer geen recht zou mogen hebben een strafadvies te geven nu de officier van justitie dat ook mag. Die vergelijking miskent echter de onderliggende procesposities en bijbehorende verantwoordelijkheden (Slachtofferhulp Nederland, 2013:4). 
ces (Raad voor de rechtspraak, 2013: 9). ${ }^{27}$ Dat lijkt misschien spitsroeden lopen voor de rechter, maar legt de verantwoordelijkheid wel waar die hoort: bij de rechter. Bovendien zou het een legalisering betekenen van de huidige praktijk, waarbij de wetsuitleg - met inachtneming van de door de wetgever beoogde verruiming kan worden aangevuld met duidelijke instructies vanuit de beroepsvereniging en richtlijnen op grond van de jurisprudentie van de Hoge Raad.

In dit verband ook is het nodig aandacht te vragen voor de noodzaak van een goede voorbereiding van de rechterlijke besluitvorming met betrekking tot het door het slachtoffer ingebrachte advies. De haalbaarheid van zo'n advies moet immers worden beoordeeld in het licht van de omstandigheden van de voorliggende strafzaak. Wanneer het advies van het slachtoffer pas ter zitting wordt gegeven, kan dit aanleiding geven tot aanhouding van de zaak, omdat nader onderzoek is gewenst. Reclasseringsorganisaties dringen daarom aan op uitwisseling en overleg vóór de zitting, zodat bij het opstellen van hun advies rekening gehouden kan worden met de wensen van het slachtoffer met betrekking tot gedragsverandering van de verdachte. Zo'n uitwisseling van informatie zou bijvoorbeeld via Slachtofferhulp Nederland kunnen verlopen. Overigens leeft een soortgelijke wens ten aanzien van de ZSM-afdoening, ${ }^{28}$ onder andere met betrekking tot het uitbrengen van een advies over een eventuele, in het slachtofferadvies neergelegde wens tot herstelbemiddeling.

\section{Afsluiting}

Duidelijk moge zijn dat het kabinetsbeleid, ondanks het voorbehoud met betrekking tot het vervolgingsmonopolie, de voorbode is van ver(der)gaande slachtofferparticipatie in het Nederlandse strafproces. Hoewel daar op onderdelen een zekere aanleiding voor bestaat, is de invoering van een adviesrecht een brug te ver. Naast het gegeven dat zo'n rechtsfiguur systematische bezwaren oproept, is er ook onvoldoende praktische aanleiding toe. Niet nagelaten dat het streven om wetgeving te baseren op een evidence-based approach bijval behoeft, moet met respect voor de 'goede bedoelingen' worden gewaakt voor het 'naar de politieke hand zetten' van victimologische gegevens. In dit geval lijkt niet de wens van (een substantiële groep) slachtoffers, maar die van de politiek de vader van de gedachte te zijn. De observatie van de Raad voor de rechtspraak dat de wetgever beoogt een beperkte groep slachtoffers van dienst te willen zijn, snijdt hout. Dat is overigens niet alleen het geval voor het hier besproken spreekrecht, ook voor andere beleidsvoornemens geldt dat de focus (te) eenzijdig ligt op selecte groepen kwetsbare slachtoffers (Groenhuijsen, 2014). Dat is enerzijds begrijpelijk: waar de

27 Een soortgelijke oplossing is gevonden voor de beoordeling van de vordering door de benadeelde partij (art. 51f Sv). Toen de wetgever bij de laatste wetswijziging het ruime criterium 'onevenredige belasting' introduceerde, is door het Landelijk Overleg Strafsecties een handleiding opgesteld. Daarnaast geldt als richtsnoer natuurlijk de rechtspraak van de Hoge Raad.

28 ZSM staat voor 'Zo Snel, Slim, Selectief, Simpel, Samen en Samenlevingsgericht Mogelijk' en heeft betrekking op een versnelde afdoening van relatief eenvoudige strafzaken door het Openbaar Ministerie buiten de strafrechter om, zie www.om.nl/onderwerpen/zsm. 
kwetsbaarheid en het lijden het grootst zijn (of wellicht lijken te zijn), neigt men snel naar het bieden van bescherming. Niettemin kan dit leiden tot een versmalling van het slachtofferbeleid, met daarin gelegen verwaarlozing van de noden van andere substantiële groepen slachtoffers. Ook zij hebben legitieme aanspraken, zij het dat die wellicht wat minder uitgesproken (politiek) zijn. Belangrijk ook is de observatie van Groenhuijsen dat zo'n eenzijdige focus kan leiden tot polarisatie van het slachtofferdebat en kan omslaan in 'slachtoffermoeheid' (Groenhuijsen, 2013). Weliswaar waakt de wetgever inmiddels op papier voor het hanteren van een ideaaltypisch slachtofferprofiel, maar in de 'praktische' uitwerking via beleid en wetgeving neigt men daarop niettemin terug te vallen (Van Dijk, 2008). Dat is indachtig het abstracte, ideaaltypische karakter van beleid en wetgeving begrijpelijk, maar noodzaakt juist daarom tot een kritische beschouwing van (concept)beleid en (concept)wetgeving. Wat betreft het voorgestelde adviesrecht zijn door praktijk en wetenschap voldoende inzichten en bezwaren aangereikt om de invoering daarvan te heroverwegen. Niet in het minst vanwege de subsidiariteit daarvan in het licht van wat victimologisch onderzoek leert over de aard van slachtofferbehoeften aan victim voice. Er zijn immers, zoals het voorstel van de Raad voor de rechtspraak laat zien, andere, minder ingrijpende wegen die naar Rome kunnen leiden.

\section{Referenties}

Aanwijzing Slachtofferzorg, Stcrt. 2010, 20476.

Bednarova, J. (2011). The heart of the criminal justice system: a critical analysis of the position of the victim. Internet Journal of Criminology, www.

internetjournalofcriminology.com/Bednarova_The_Heart_of_the_Criminal_Justice_ System.pdf.

Boom, A. ten \& K.F. Kuijpers (2007). Behoeften van slachtoffers van delicten. Den Haag: WODC.

Cassell, P. \& E. Erez (2011). Victim Impact Statements and Ancillary Harm: The American Perspective. Canadian Criminal Law Review, 169-172.

Davies, R. \& C. Mulford (2009). Victims Rights and The Remedies: Finally Getting Victims their Due. Journal of Contemporary Criminal Justice, 198-208.

Dijk, J. van (2008). Slachtoffers als zondebokken. Antwerpen: Maklu.

Doak, J., R. Henham \& B. Mitchell (2009). Victims and the stencing process: developing participatory rights?. Legal Studies, 651-677.

Edwards, I. (2004). An ambiguous participant. British Journal of Criminology, 967-982.

Englebrechts, C. (2001). The struggle for ownership of conflict. Criminal Justice Review, 129-151.

Erez, E., J. Globokar \& P. Ibarra (2014). Outsiders inside: Victim management in an era of participatory reforms. International Review of Victimology, 169-188.

Erez, E. \& P. Tondonato (1992). Victim participation in sentencing and satisfication with justice. Justice Quartely, 393-419.Fonds Slachtofferhulp (2013). Advies concept wetsvoorstel uitbreiding spreekrecht en schadefonds, www.fondsslachtofferhulp.nl/wpcontent/uploads/2013/11/Advies-uitbreiding-spreekrecht-en-schadefonds.pdf.

Groenhuijsen, M.S. (2013). Waarheidsvinding in het strafrecht. In: Nederlandse Juristen Vereniging, Waarheid en waarheidsvinding in het recht, Deventer: Kluwer, 231-305. 
Groenhuijsen, M.S. \& G. Knigge (2002), Dwangmiddelen en Rechtsmiddelen. Derde interimrapport onderzoeksproject Strafvordering 2001. Groningen: Universiteit Groningen, 804-808.

Groenhuijsen, M.S. \& N.M. Kwakman (2002). Het slachtoffer in het vooronderzoek. In: M.S. Groenhuijsen, M. (2014). The development of international policy in relation to victims of crime. International Review of Victimology, 31-48.

Kamerstukken II 2012-2013, 33 552, nr. 6.

Keulen, B.F., A.A. van Dijk, E. Gritter, N.J.M. Kwakman \& K. Lindenberg (2013). Naar een tweefasenproces?. Den Haag: WODC.

Kool, R. (2014). Dry-eyed Justice?. Ars Aequi, 598-606.

Kool, R., R. Passier \& A. Beijer (2006). Evaluatie implementatie schriftelijke slachtofferverklaring. Utrecht: Willem Pompe Instituut.

Kool, R. \& G. Verhage (2014). Are you being served? The Victim Impact Statement: a Comparative Perspective. Utrecht Law Review (forthcoming).

Laxminarayan, M. (2013). The Heterogeneity of Crime Victims: Variations in Procedural and Outcome Preferences. Nijmegen: Wolf Legal publishers.

Leferink, S.B.L. \& K.H. Vos (2008). Spreekrecht en schriftelijke slachtofferverklaring: recht of kans?. Utrecht: Slachtofferhulp Nederland.

Lens, K., A. Pemberton \& S. Bogaerd (2013). Heterogeneity in victim participation: A new perspective on delivering a Victim Impact Statement. European Journal of Criminology, 479-495.

Lens, K.M.E., A. Pemberton \& M.S. Groenhuijsen (2010). Het spreekrecht in Nederland: Een bijdrage aan het emotioneel herstel van slachtoffers?. Tilburg: INTERVICT.

Lünnemann, K.D. \& A.G. Mein (2014). Maatregelen ter voorkoming van secundair en herhaald slachtofferschap. Utrecht: Verweij Jonker Instituut.

McGonigle, B.N. (2011). Procedural justice? Victim participation in international criminal proceedings. Antwerpen: Intersentia.

Ministerie van Veiligheid \& Justitie (2013). Recht doen aan slachtoffers. Kamerstukken II 2012-2013, 33 552, nr. 2.

Ministerie van Veiligheid \& Justitie (2013a). Eindrapport beleidsdoorlichting. Artikel 34.4 Slachtofferzorg. Kamerstukken II 2013-2014, 33 552, nr. 7.

Pemberton, A. (2004). Mening van slachtoffer overwegend negatief. Puntkomma, 12-13.

Pemberton, A. (2005). Het spreekrecht, vergelding of herstel?. Tijdschrift voor Herstelrecht, 34-43.

Pemberton, A. \& S. Reynears (2011). The controversial nature of victim participation: therapeutic benefits in victim impact. In: E. Erez, M. Kichling \& J-A. Wemmers, Therapeutic Jurisprudence and Victim Participation in Criminal Justice: International Perspectives. Carolina: Academic Press, 229-249.

Raad voor de rechtspraak, Advies Conceptwetsvoorstel uitbreiding spreekrecht, 19 december 2013, www.rechtspraak.nl/Organisatie/Raad-Voor-De-Rechtspraak/ Wetgevingsadvisering/Wetgevingsadviezen2013/2013-49-Advies-

Conceptwetsvoorstel-Wijziging-van-het-Wetboek-van-Strafvordering-ter-aanvullingvan-het-spreekrecht.pdf.

Roberts, J. \& E. Erez (2004). Communication in sentencing: Exploring the Expressive Function of Victim Impact Statements. International Review of Victimology, 223-245.

Sas, A. (2013). Het belang van het adviesrecht voor slachtoffers. NJB-blog, http://njb.nl/ blog/het-belang-van-het-adviesrecht- voor-slachtoffers.12359.lynkx.

Slachtofferhulp Nederland (2013). Advies. www.slachtofferhulp.nl/Actueel/20111/ Uitbreiding-spreekrecht. 
Sas, A. \& H. Crielaars (2013). Spreekrecht plus komt tegemoet aan behoeften slachtoffers, www.slachtofferhulp.nl.

Staatsblad (2012), 345 resp. 370, Wet wijziging Wetboek van Strafvordering ter uitbreiding van het spreekrecht van slachtoffers in het strafproces.

Stokkom, B. van (2011). Victim needs, wellbeing and 'closure': is revenge therapeutic?. In: E. Erez et al., Therapeutic Jurisprudence and Victim Participation in Criminal Justice: International Perspectives, 207-229.Teeven, F. (staatssecretaris van V\&J) (2013), Visie op slachtoffers, 22 februari 2013, p. 3-4 (Kamerbrief).

Timmermans, M., F. van den Tillaart \& G. Homburg (2013). Eerste meting slachtoffermonitor: ervaringen van slachtoffers met justitiële slachtofferondersteuning. Deel 1 en 2. Amsterdam: Regioplan.

Victim Support Europe (2013). Handbook for Implementation of Legislation and Best Practice for Victims of Crime in Europe, par. 2.2, http://ec.europa.eu/justice/events/assisesjustice-2013/files/contributions/51.1.

1374573250handbookforimplementationandbestpracticeforvictimsofcrimeineurope 23713_en.pdf.

VVD \& PvdA. Bruggen slaan. Regeerakkoord VVD-PvdA (oktober 2012), www.rijksoverheid. nl/documenten-en-publicaties/rapporten/2012/10/29/regeerakkoord.html.

Wemmers, J.A. (2009). Where do they belong? Giving victims a place in the criminal justice process. Criminal Law Forum, 405-406.

Wemmers, J.A. \& K. Cyr (2004). Victim's Perceptions on Restorative Justice: How Much Involvement are Victims Looking for. International Journal of Victimology, 259-274. 